\title{
Rivers in the name of Sources for the Renewable Energy
}

Authors: $\quad$ Bujar Q. Bajçinovci, Modest Gashi, Vlora Aliu, Bard Bajçinovci, Uliks Bajçinovci

Submitted:

16. December 2019

Published:

Volume:

Issue:

17. December 2019

6

Affiliation:

Languages:

Keywords:

Categories:

DOI:

11

University of Prishtina, Faculty of Civil Engineering and Architecture, Kosovo.

English

Rivers, Kosovo, Renewable Energy, Environment, Biodiversity, Urban Planning.

Visual Arts, Architecture and Design

Abstract:

10.17160/josha.6.11.620

Kosovo's water capacities are being ruined in the name of sources for renewable energy. Surely, those constructions for renewable energy have sparked fears of the worst wildlife damages and biodiversity of the environment. The study presented in this paper investigated the water resources of Kosovo. Focusing on the river volumes, legislation, biodiversity, sources for renewable energy, and urban planning issues. The current and possible degraded state of the environment in the name of sources of renewable energy are not acceptable, even more, when the water capacities are being ruined and creating cumulative impacts on river systems, disrupting the landscape and beauty of their characters, and affecting the function of their habitats. Surely, hydropower plants are potential of renewable energy, but it must be wise planned and carefully located, never affecting the public health and community wellbeing.

\section{JOSHA Jumnal stsemene. Humanities and Arts}




\title{
Rivers in the name of Sources for the Renewable Energy
}

\author{
Bujar Bajçinovci ${ }^{1 *}$, Modest Gashi ${ }^{2}$, Vlora Aliu ${ }^{1}$, Bard Bajçinovci ${ }^{3}$, Uliks Bajçinovci ${ }^{3}$ \\ ${ }^{1}$ University of Prishtina, Faculty of Architecture, Kosovo. \\ ${ }^{2}$ UN-Habitat, Duty station Mitrovica, Kosovo. \\ ${ }^{3}$ UBT- Higher Education Institution. Faculty of Architecture and Spatial Planning, Kosovo. \\ Email:bujar.bajcinovci@uni-pr.edu,_modest.gashi@unhabitat-kosovo.org,vlora.aliu@uni-pr.edu, \\ bb34218@ubt-uni.net,ub35398@ubt-uni.net
}

\section{Abstract:}

Kosovo's water capacities are being ruined in the name of sources for the renewable energy. Surely, those constructions for the renewable energy have sparked fears of the worst wildlife damages and biodiversity of the environment. The study presented in this paper investigated the water resources of Kosovo. Focusing on the river volumes, legislation, biodiversity, sources for the renewable energy, and urban planning issues. The current and possible degraded state of environment in the name of sources of renewable energy are not acceptable, even more, when the water capacities are being ruined and creating cumulative impacts on river systems, disrupting the landscape and beauty of their characters, and affecting the function of their habitats. Surely, hydropower plants are potential of renewable energy, but it must be wise planned and carefully located, never affecting the public health and community wellbeing.

Key words: Rivers, Kosovo, Renewable Energy, Environment, Biodiversity, Urban Planning.

\section{INTRODUCTION}

Kosovo's water capacities are being ruined in the name of sources for the renewable energy. Surely, those projects for the renewable energy, especially renewable hydropower frameworks, have sparked fears of the worst wildlife damages of these rivers. Protests against these sustainable constructions have begun to take place in various parts of Kosovo, furthermore, endangering the supply of potable water as well as several environmental hazards of the region. Citizens actions have also been joined by leaders of local and central institutions, civil society organizations and nature lovers [1]. "Cities are complex ecosystems with specific phenomenon's directly reflected in our health, natural resources, economic, social and aesthetic fields. They are open integrated systems and huge organisms with specific and complex metabolism that transform vast amount of energy, generate huge amount of waste and emanate a number of specific environmental phenomenon's and activities" [2], hence, urban expansion of city development presents spatial evolving framework with each city physiognomy, aiming to achieve the better quality of life, with primary features that affect public health and health wellbeing [2]. Actually, in major cases in 
Kosovo the law for water has been violated, where it is very clearly stated that concessions and the investments cannot be granted if it concerns resources and violate the use of drinking water.

\section{MATERIALS and METHODS}

The study presented in this paper investigated the water resources of Kosovo, where water capacities are being ruined in the name of sources for the renewable energy. Focusing on the river volumes, legislation, sources for the renewable energy, and urban planning issues. The research methods consist of empirical observation through field, and literature review. In order to receive a clearer data, the research is made within spatial regulation, Municipality actions, reaction of ethnic groups, focusing on the bioclimatic environment regarding to the morphology of the affected regions. The data collected include maps, composition of urban structure, attributes of the space, dimensions of locations for these "environmental activities". The additional data for this paper is based on the analysis of the Ministry of the Environment. Protection of water resources is a moral, ethical and human obligation of everyone as water is an essential factor to life, health, food, culture, production and renewable energy. The need for fresh water is one of the greatest environmental issues globally today. Data show that more than 1.5 billion people worldwide do not have access to drinking water, while approximately three billion people do not have appropriate sanitary services. "In view of the current urbanization trend in the world, until 2025 approximately three billion people will need water supply, in Kosovo, as in many other countries of the world, the human health and well-being is increasingly threatened by poor water quality or lack of fresh water. Based on data provided by Kosovar institutions, approximately $80 \%$ of the population is supplied from the public water supply system. Protection, preservation and monitoring of the quality of water resources is one of the greatest environmental challenges of our society. Industrial development, urbanization and intensive agriculture are some of the factors causing water pollution. Despite continuous efforts, uncontrolled use of water resources and damage of river beds remain as factors contributing to the degradation of our water resources" [3]. "As shown in the table 2, about $69.6 \%$ of the population in Kosovo is supplied with water from public systems managed by regional water companies, $29 \%$ from independent systems not managed by regional water companies, and $0.7 \%$ of the population does not have access to the water supply system. 
Based on the performance report of regional water companies, coverage with water supply services in their areas was $82 \%$ in 2013, which is $4 \%$ higher than the 2012 percentage, and this trend is going accordingly to the grow objectives" [3].

Table 1. Basic data on rivers and river basins of Kosovo $[3,4]$.

\begin{tabular}{|c|c|c|c|c|c|c|}
\hline River & $\begin{array}{c}\text { Area (S) } \\
\mathrm{km}^{2}\end{array}$ & $\begin{array}{l}\text { Length of } \\
\text { river }(\mathrm{L}) \\
\mathrm{km}\end{array}$ & $\begin{array}{c}\text { Flow (Q) } \\
\mathrm{m}^{3} / \mathrm{s}\end{array}$ & $\begin{array}{c}(\mathrm{q}) \\
1 / \mathrm{sek} / \mathrm{km}^{2}\end{array}$ & $\begin{array}{l}\text { Slope } \\
\%\end{array}$ & $\begin{array}{l}\text { Perimeter of } \\
\text { basin }(\mathrm{Km})\end{array}$ \\
\hline Drini i Bardhë & 4340.14 & 110.7 & 61.7 & & 2.1 & 409.8 \\
\hline Sushica & 49.4 & 17.25 & & & 9.4 & 32 \\
\hline LB.Pejës & 464,8 & 57 & 10.21 & 24.13 & 2.5 & 128 \\
\hline LB.Deçanit & 259,3 & 53 & 7.84 & 42.46 & 3.2 & 105 \\
\hline Ereniku & 519.3 & 51.74 & 12.16 & 26.73 & 3.9 & 109 \\
\hline Istogu & 405.3 & 19.74 & 6.98 & & 4.5 & 87 \\
\hline Klina & 458.7 & 72.12 & 2.8 & 4.92 & 4.5 & 126 \\
\hline Mirusha & 336,7 & 37 & 1.661 & & 1.7 & 83 \\
\hline Toplluha & 495 & 34.05 & 3.44 & & 3.5 & 108 \\
\hline LB.Prizrenit & 247,8 & 36.07 & 6.49 & 29.68 & 7.4 & 77 \\
\hline Plava, Restelic & 341.86 & 22.12 & 5.25 & 20.79 & 5.9 & 90.56 \\
\hline Basin total & 4682 & 110.7 & 61.01 & & 2.1 & 409.8 \\
\hline Ibri & 4044.21 & 89.50 & 36.4 & 6.39 & 0.3 & 436.8 \\
\hline Sitnica & 2912 & 78 & 13.94 & 5.38 & 1.1 & 276 \\
\hline M.Binçes & 1564 & 76 & 8.7 & 5.99 & 1.5 & 216 \\
\hline Kriva Reka & 640.70 & 44.5 & 4.43 & 7.27 & 1.2 & 128 \\
\hline Lepenci & 653 & 50 & 8.4 & 14.91 & 4.6 & 130 \\
\hline Nerodime & 209.4 & 38.5 & & & 2.1 & 81.5 \\
\hline Total & 10907.00 & & 121.2 & & & \\
\hline
\end{tabular}

Table 2. Availability of water supply network $[3,5]$.

\begin{tabular}{l|l|l} 
Nature of supply & Household units & $\%$ \\
\hline Water system provided by public service & 204,365 & $69.6 \%$ \\
\hline Water system provided by other sources & 82,609 & $28.2 \%$ \\
\hline Pipeline water system within building outside household unit & 899 & $0.3 \%$ \\
\hline Pipeline water system outside building & 3,413 & $1.2 \%$ \\
\hline Water supply system not available & 2,157 & $0.7 \%$ \\
\hline Total & 293,443 & $100.0 \%$
\end{tabular}


Industrial and energetic operators are the greatest users of water. The greatest spenders of water in Kosovo include: KEK, Feronikel and Sharrcem. These operators are mainly supplied with water from superficial accumulating lakes. Some of the smaller industrial operators are supplied with water from the public network, whereas a few of them use well-based independent water supply systems. "The Kosovo Energy Corporation is one of the economic operators that spend most water for energy production purposes. Power Plant Kosova A is supplied with unprocessed water from the Llap River and from the Ibar- Lepenci and Batllava Lake when necessary, while Power Plant Kosova B is supplied with unprocessed water from Ibar-Lepenci. According to data provided by Kosovo Energy Corporation, the corporation used 21 million $\mathrm{m}^{3}$ of water for energy production during 2013" [3]. "New Feronikel is supplied with water for its technological processes from Bivolak Ibar- Lepenci, which is located $17 \mathrm{~km}$ away from the industry and which supplies water reservoirs located above the factory, Feronikel uses this water for industrial and drinking purposes. The industrial water is mainly used for electrical furnaces cooling, slag granulation, steam production and for gas and dust cleaning systems in convertors and electrical furnaces. The majority of the industrial water used to cool electrical furnaces is re-circulated, while most water is spent in steaming processes. According to data provided by NewCo Feronikel, approximately 1.2 million $\mathrm{m}^{3}$ of water were spent during 2013" [3]. "The cement factory Sharrcem in Hani i Elezit operates with a closed water system at all points of the production process. This system is supplied with water from sources of the Lepenc River and Dimca stream. Water is spent in this industry for conditioning furnace gases, for cooling processes in the air conditioning tower and for sanitary purposes. According to data provided by the concrete factory SharrCem, $100,000 \mathrm{~m}^{3}$ of water were used during 2013" [3].

\section{DISCUSSION}

The hydropower plants currently operating in Kosovo include the plant of Ujman with an energy production capacity of $34 \mathrm{MW}$ and five small plants contributing to the distribution network with a capacity of 11.82 MW [3]. "Other small plants include those in Dikanc, Burim and Prizren. Another operational hydroelectric plant in Kosovo is that of Kozhnjer in Deçan, which has been given with concession and produces a small amount of energy. Kosovo has numerous rivers and 
streams with a hydro-energetic potential that may be used to produce electrical energy. The western part of Kosovo has the hydro-energetic potential of Drini i Bardhe, which comprises more than half of the hydro-energetic potential of Kosovo. The most important hydroelectric plant that may be built in Kosovo is that of Zhur located in the flow of Drini i Bardhe with a capacity of 0.377 Twh/year. The flows of rivers Drini i Bardhe, Iber, Morava, Lepenc and Llap have a significant potential for electrical energy production" [3].

Table 3. Basic data on the capacity of planned hydropower-plants [6] [3].

\begin{tabular}{|c|c|c|c|c|}
\hline Name of HP & $\begin{array}{l}\text { Potential capacity } \\
{[\mathrm{MW}]}\end{array}$ & $\begin{array}{l}\text { Planned production } \\
\text { GWh }\end{array}$ & $\begin{array}{l}\text { Flow } \mathrm{m}^{3} / \\
\mathrm{sec}\end{array}$ & River \\
\hline Kuqishta & 3.9 & 19.0 & 6 & \multirow{3}{*}{ Peja } \\
\hline Drelaj & 6.2 & 29.6 & 6.5 & \\
\hline Shtupeq & 7.6 & 37.2 & 8 & \\
\hline Bellajë & 5.2 & 26.1 & 5 & \multirow{2}{*}{ Deçani } \\
\hline Deçani & 8.3 & 40.7 & 6.5 & \\
\hline Lloçan & 3.1 & 14.4 & 1.5 & Lloçani \\
\hline Mali & 3 & 18.6 & 2.4 & \multirow{3}{*}{ Erenik } \\
\hline Erenik & 2 & 9.5 & 2.4 & \\
\hline Jasiq & 1.9 & 9.9 & 2.6 & \\
\hline Dragash & 2.2 & 11.5 & 5 & \multirow{2}{*}{ Plavë } \\
\hline Orçush & 5.6 & 29.2 & 7 & \\
\hline Reçan & 1.5 & 7.9 & 2.6 & Prizreni \\
\hline Brezovicë & 2.1 & 11.5 & 4.5 & \multirow{2}{*}{ Lepenc } \\
\hline Lepenci & 3.5 & 19.1 & 7.6 & \\
\hline Banjska & 0.3 & 1.7 & 0.5 & Banjska \\
\hline Batare & 1.1 & 5.6 & 2.3 & Bistrica \\
\hline Majanc & 0.6 & 3.1 & 1.5 & Kaçandoll \\
\hline Mirusha & 4.6 & 28.1 & 45 & Drini \& Deçani \\
\hline Total & 62.7 & 322.8 & & \\
\hline \multicolumn{2}{|c|}{ Hydro-plant of Zhur } & \multicolumn{2}{|c|}{ Potential capacity [MW] } & $\begin{array}{c}\text { Planned production } \\
\text { GWh }\end{array}$ \\
\hline \multicolumn{2}{|l|}{ Zhur 1} & \multicolumn{2}{|l|}{$2 \times 131$} & 342.2 \\
\hline \multicolumn{2}{|l|}{ Zhur 2} & \multicolumn{2}{|l|}{42} & 55.39 \\
\hline \multicolumn{2}{|l|}{ Total } & \multicolumn{2}{|l|}{305} & 397.6 \\
\hline
\end{tabular}

The table below summarizes the basic data regarding the capacity of planned hydro-plants and their locations. But, according to the officials in Inter-Ministerial Council on Water in the 
Government, which are declaring: "We have been engaged in this process, although not actively because it is the responsibility of the Ministry of Environment, however we have dealt with, hence, we have essentially betrayed this problem because granting the right to use water for hydropower plants and for all other uses must be granted by concession, and not by water permit, here we have a legal violation at the outset and this violation was committed by those who issue this permit which is the Ministry of Environment because the concession is different from the permit, because it is a competitive and transparent process. Hence, there are no individual desires for the new hydropower plant locations, but the state and the ministry determine the locations where there are hydropower plant capacities. In Kosovo, no concessions were implemented at all and water permits were issued at the request of investors" [7]. Kosovo as a member of the Energy Community Treaty has pledged to have at least $25 \%$ of its energy from renewable energy sources by 2020 . Studies have identified more than 77 sites where hydropower plants can be built. These plans were widely accepted by Kosovo institutions, despite the scarce availability of water in Kosovo [1]. It is estimated that Kosovo has $1600 \mathrm{~m}^{3}$ /water/year per capita [3]. The main hydrological feature in Kosovo is the unequal and inadequate distribution of water resources in relation to demand. The water energy potential in Kosovo is very low and it has been used until now to a very modest extent [3]. Protected areas are important for nature conservation. "Remarkably, about 1,000 of the 3,000 hydropower projects in the Balkans are planned in protected areas such as National Parks and Natura 2000 sites, which Kosovo is also a member. Furthermore, the law on nature protection prohibits "touch" of national parks, prohibiting the economic use of natural goods" [1].

\section{CONCLUSION}

The current and possible degraded state of environment in the name of sources of renewable energy are not acceptable, even more, when the water capacities are being ruined. Those environmental actions require specific responsibilities and activities, especially when the state is directly linked to the public health and quality of life. Strategic Environmental Assessment for Spatial Planning of the "Bjeshkët e Nemuna National Park", published by the Kosovo Environmental Protection Agency, an institution within the Ministry of Environment and Spatial Planning, MESP, declares: "The development of new hydropower projects should be discouraged, as they create cumulative impacts on river systems, disrupting the landscape and beauty of their characters, and affecting the function 
of their habitats." [8]. Surely, hydropower plants are potential of renewable energy, but it must be wise planned and carefully located, furthermore, never affecting the public health and community wellbeing.

\section{REFERENCES}

[1] Ramadani, D. (2019). https://kallxo.com/gjate/shkaterrimi-i-lumit-lepenc-nga-hidrocentralet-evogla/. [Accessed: October 2019].

[2] Bajçinovci, B., Jerliu, F. (2016). Challenges of Architectural Design in relation to Environment and Air Pollution. A Case study: Prishtina's first public parking garage. Journal of Science, Humanities and Arts. Volume 3, Is. 7. DOI: 10.17160/josha.3.7.254

[3] MESP. (2015). Report on the State of Water. Ministry of Environment and Spatial Planning Kosovo-Environmental Protection Agency, 2015.

[4] Kosovo Waters Master Plan. (2017). http://knmu.kryeministriks.net/repository/docs/Water_Strategy final.pdf, [Accessed: October 2019].

[5] KSA. Kosovo population census 2011. http://ask.rks-gov.net/en/kosovo-agency-ofstatistics/social/population-and-housing-census, [Accessed: October 2019].

[6] Daniel M. Kammen et al. (2012) Sustainable Energy Options for Kosovo. University of California, Berkeley, USA.

[7] Lajçi, A. Inter-Ministerial Council on Water in the Government of Kosovo. Hydropower plants should be built on concession rather than water permits. https://kallxo.com/lajm/qeveriahidrocentralet-duhet-te-ndertohen-me-koncesion-e-jo-leje-ujore/, [Accessed: October 2019].

[8] MESP, in collaboration UN, Habitat. (2015). Environmental Strategic Assessment for The Spatial Plan of "Bjeshket e Nemuna" National Park. Ministry of Environment and Spatial Planning Kosovo-Environmental Protection Agency. https://www.ammkrks.net/repository/docs/VSM__PHPK_BN_160415_(shq).pdf, [Accessed: October 2019]. 